FACTA UNIVERSITATIS

Series: Economics and Organization Vol. 16, No 4, 2019, pp. 429 - 442

https://doi.org/10.22190/FUEO1904429S

Preliminary Communication

\title{
JOB SATISFACTION OF ACADEMIC STAFF IN THE HIGHER EDUCATION SYSTEM OF SERBIA: A PILOT STUDY
}

UDC 371.213.3:378]:005.96(497.11)

\author{
Agneš Slavić ${ }^{1}$, Julija Avakumović ${ }^{2}$, Nemanja Berber ${ }^{1}$ \\ ${ }^{1}$ University of Novi Sad, Faculty of Economics in Subotica \\ ${ }^{2} \mathrm{PhD}$ student - University of Novi Sad, Faculty of Economics in Subotica
}

\begin{abstract}
In the turbulent business environment of today, the competitiveness of all organizations is primarily based on intangible resources. Due to global competition, the permanent actualization of employee competencies is imperative for the long-term survival of organizations. The higher education system bears a special responsibility in this process, as it provides an upgrade for the development of the previously obtained competencies of future employees. Higher education is the system focused on dual core functions of knowledge creation and knowledge transmission through the processes of research and teaching (Houston et al, 2006, 17). To ensure high-level competences in future employees, it is crucial for the higher education system (teaching staff) to provide students with the latest knowledge in their field. The job satisfaction of academic staff is reflected in the quality of teaching and communicating with students (Runhaar, 2017, 646-647). The aim of this paper is to determine the level of general and partial satisfaction of teaching staff at the institutions of higher education in the Republic of Serbia. The method implemented for determining the level of satisfaction, was Spector's Job Satisfaction Survey - JSS (Spector, 1985), in the form of an on-line questionnaire. The pilot research was conducted in December 2018 and January 2019. The sample consists of 58 respondents - teachers from higher educational institutions in the Republic of Serbia. The results of general job satisfaction survey indicate that teachers are generally ambivalently satisfied with their job, they are neither satisfied, nor dissatisfied. The results of partial satisfaction show that teaching staff is most satisfied with the nature of their job.
\end{abstract}

Key words: higher education, job satisfaction, job satisfaction of academic staff, general job satisfaction, partial job satisfaction

JEL Classification: I23, J28, M54

Received September 03, 2019 / Accepted October 07, 2019

Corresponding author: Nemanja Berber

University of Novi Sad, Faculty of Economics in Subotica, Segedinski put 9-11, 24000 Subotica, Serbia

E-mail: berber@ef.uns.ac.rs

() 2019 by University of Niš, Serbia | Creative Commons Licence: CC BY-NC-ND 


\section{INTRODUCTION}

Knowledge and human resources are the basis of every society. Employee development is directly related to the performance of the employees and also to the performance of the organization (Szabó et al., 2019). Bogićević Milikić (2019) points out that learning and development is directed towards improving individual and organizational performance through the development of an employee's capacity to contribute to the organization's efficiency. Stronger human resource development requires stronger links between the education and research systems and all other sectors, in order to make better use of existing and created resources through higher education (RS Scientific and Technological Development Strategy, 2016, 5). Education system of a society is a key determinant of its development (Jovanović-Kranjec \& Despotović, 2018), while investments in education, research and development, and innovation result in knowledge-driven and sustainable development (Jednak et al., 2018; Krstić et al., 2018), and higher competitiveness of a country (Jovanović, 2018).

The situation in Serbia's education system has been influenced by social, political and economic changes in the past two decades. There is an expressed need for reforms in education in order to rebuild the school system, as well as improve and develop education, as a part of the complex reforms of the whole society (Hebib \& Spasenovic, 2011, p. 376).

In Serbia, the modern reforms of higher education system started with the implementation of the Bologna Declaration and the establishment of the Commission for Accreditation and Quality Assurance (The Law on Higher Education of the Republic of Serbia, 2005), which was revised in 2018 into the National Accreditation Body (The Law on Higher Education of the Republic of Serbia, 2017). The goal of the reforms in the education system was to modulate the existing curriculum and study plans with those similar in the European Higher Education Area, thereby enabling the identification and recognition of a previously acquired education level. The generated "European model" in higher education system in Serbia, has normative (cooperation, dialog, variation, mobility) and structural dimensions (Bologna process). Given the teaching staff's international orientation, it has become easier to participate in international networks of higher education.

To achieve the established mission and vision, the Strategy of education determines specific objectives: stimulating excellence and relevance of scientific research in Serbia; strengthening the integration of science, economy and society to stimulate innovations; establishing efficient management system in science and innovation in Serbia; assuring excellence and availability of human resources in science, economy and social affairs; promoting international cooperation of science and innovation; increasing investment in research and development through public funding and through stimulating the funding from the business sector (Strategy on Scientific and Technological development of the Republic of Serbia for the period 2016-2020, 2016, p. 8).

The current Law on higher education in Serbia defines these job positions at faculties: full professor, associate professor, assistant professor and assistant, while at colleges and at colleges of applied studies these are: professor of applied studies, higher college teacher, college teacher and assistant at college. Less than $10 \%$ of Serbia's population has a degree in higher education, in fact only 6.5\% (Statistical Pocketbook of Serbia, 2018, p. 122-130).

Academic staff at higher educational institutions has to be equipped with the latest knowledge in their field when teaching their students. The motivation and ability of 
academic staff to develop students' competences are influenced by many factors, but among them the satisfaction with their own working environment is one of the most crucial ones (Runhaar \& Sanders, 2016, p. 806-808). A positive and healthy working environment will result in a satisfied and motivated member of academic staff (Stankovska et al., 2017, p. 159). This is especially true since higher education working environment is the key to organization success and competitive advantage (Pham-Thai, 2018, p. 951). The results of an organization are the sum of their employees' results; actually, the organization's results mirror their results of the employees' job satisfaction or dissatisfaction (Spector, 1997, p. 55).

The aim of this paper is to determine the level of job satisfaction of academic staff at higher educational institution in Serbia, through the level of general job satisfaction, as well as to determine the level of partial satisfaction concerning the nature of work, co-workers, pay, promotion, fringe benefits, contingent rewards, communication, supervision, and working conditions.

\section{THEORETICAL BACKGROUND}

\subsection{Job Satisfaction}

Job satisfaction is a vital factor in the field of human resource management, based on employee's perception - to what extent does the job offer exactly what the employee expects from it (Amaresena et al, 2015, p. 541; Stankovska et al, 2017, p. 160). Job satisfaction can be considered as a general attitude towards work, or satisfaction according to various dimensions of work, such as: pay, job promotion possibility, superiors and colleagues (Zimanji, Šušnjar, 2007, p. 135). It is an enjoyable or positive emotional state resulting from the appraisal of one`s job or job experiences (Locke, 1976; Đorđević et al., 2017, p. 265). Paul E. Spector highlighted three reasons concerning the importance of job satisfaction: humanitarian perspective of work, positive emotional attitude of job and totality positive effect on organization performance (Spector, 1997, p. 2).

Job satisfaction can be defined as a cognitive, affective and evaluative individual reaction to a job. The cognitive component contains what a person believes to know about the subject of attitude; the evaluative component refers to how much the given person likes or dislikes the goods (or person); and behavioristic component contains certain predisposition to acting in a certain direction (Zimanji, Šušnjar, 2007, p. 135). Job satisfaction is an attitude - a feeling of relative like or dislike towards something. Employees' attitudes consist of feelings, thoughts, and intentions to act. An employee as an individual often adjusts their own attitude in accordance with the attitude of the group (team) he/she belongs to. Generally, attitudes are acquired for a long time, so that job satisfaction or dissatisfaction occurs when an employee receives more and more information about his/her work place. If the causes of job satisfaction are determined, they cannot be ignored later, because those causes may vary and lead to job dissatisfaction. Permanent monitoring of job satisfaction is a need based on the fact that job satisfaction is a dynamical attitude. Job satisfaction is a part of life satisfaction and has interactive influence. Apart from job satisfaction, life satisfaction is affected by family, religion, policy and vacation, too (Newstrom, 2007, p. 204-205).

The antecedents of job satisfaction can be classified into two major categories. First, the job environment itself and factors associated with the job. This includes how people 
are treated, the nature of the task, relations with other people in the workplace, and rewards. Second, there are individual factors such as personality and prior experiences. The two categories of antecedents often work together in order to influence employee satisfaction. The basic assumption of job characteristics theory is that people can be motivated by the satisfaction they experience through performing their tasks. When they find their work to be enjoyable and meaningful, people will like their jobs and will be motivated to perform their jobs well (Spector, 1997, p. 30-31).

If there is harmony between the personality of the employee and the job requirements, the employees will better use their knowledge and ability, which is beneficial and allows them to fulfill their needs for achievement, as well as achieve greater job satisfaction. Finding harmony of personality and job requirements is important for the organization, especially in relation to work quality (Hadžić \& Nedeljković, 2010, p. 171).

Job satisfaction has a direct impact on professional (Shamina, 2014, p. 1-3) and organizational commitment (Trivellas \& Santouridis, 2016, p. 171) and also motivates employees to increase their productivity (Khan et al, 2014, p. 54). Job satisfaction, as an attitude, has significant relations with organizational performances, job performances of employees, organizational citizenship behavior (Ivanović-Đukić et al., 2018, p. 13), organizational justice (Đorđević et al., 2018, p. 148), turnover intentions and absenteeism (Došenović, 2018, p. 365).

Research on job satisfaction should include demographic factors such as gender, age, years of working experience, number of years spent on the work position and level of work position (Castillo \& Cano, 2004, p. 68; Hadžić \& Nedeljković, 2010, p. 187).

The measuring of job satisfaction is important, because the results may indicate differences between employee expectations of the job and what the job truly offers (Amaresena et al, 2015, p. 544; Hadžić \& Nedeljković, 2010, p. 42-52). Today, there are different models of measuring job satisfaction, where the dependent variable is job satisfaction, and the independent variables can be compensation, work environment, characteristics of the job, organizational decisions, leadership, interpersonal relationships, self-respect, workload, autonomy, social recognition and supervision (Azumah et al, 2017, p. 3).

\subsubsection{Job satisfaction of academic staff in higher education}

Job satisfaction is important to perform any job adequately. While satisfaction with the job is an important phenomenon in any sector, it is especially vital in the education sector (Nigama et al, 2018, p. 2645). Job satisfaction of academic staff is crucial to retain teachers and a significant determinant of the commitment of academic staff, which acts as feedback regarding efficiency of work in a school as organization (Munir \& Khatoon, 2015, p. 454)

Job satisfaction of the staff employed in educational institutions refers to the effective relation of teachers to their role as lecturers and to the function of the observed relation between what employees expect from the teaching and what the educational institution really offers them (Jošanov-Vrgović, 2012, p. 16).

Satisfaction of academic staff brings benefits to teachers, students and educational institution. Teachers play an important role in creating better environment and working atmosphere at universities, therefore, teachers who are satisfied with their job can significantly contribute to how successful the educational institution as an organization is (Ahmad et al., 2018). 
Job satisfaction of employees in higher education is reflected through a better chance for promotion and professional development (Al-Rubaish et al., 2011, p. 1), status within the society (Saiti \& Papadopoulos, 2014, p. 74), research funding (Ali, 2009, p. 291), flexible working time (Popović et al., 2015, p. 34), good work environment (Stankovska et al., 2017, p. 160), elements of organizational culture (Andreassi et al., 2014, p. 56; Ali, 2009, p. 290), good working experience (Qazi \& Jeet, 2017, p. 179) and adequate compensation (Khalid et al., 2012, p. 128; Nandan \& Krishna, 2013, p. 134; Bodla et al., 2014, p. 23).

Research about job satisfaction can help management and teachers to further develop the quality of education (Toker, 2011, p. 156).

In a study at the state university in Skopje (North Macedonia), the authors used the JSS questionnaire (Job Satisfaction Survey: Spector, 1985) to measure general job satisfaction. JSS contains 36 items, grouped in 9 partial indicators related to employees' attitude about the job: payment, promotion, supervision, benefits, rewards, procedures, colleagues, nature of job, and communication at workplace. The results of general job satisfaction indicated that academic staff are satisfied with their job, while the analysis of partial indicators show that academic staff are satisfied with supervision but dissatisfied with benefits and rewards (Stankovska et al., 2017, p. 163).

To determine the relation between HRM practice and job satisfaction, authors Bodla et al. (2014) used correlation and regression analysis in their study. The authors proved that the increase of working performance results in the increase of job satisfaction level, and there is a positive relation between performance appraisal and job satisfaction. The regression coefficient shows that carrier planning and pay increase has a positive and significant impact on the increase of job satisfaction of academic staff.

A study at a state university in Sri Lanka on the assessment of job satisfaction among academic staff used 5-point Likert's scale. The result concerning general job satisfaction is 3.95, which is higher than 3 (the neutral value in this example) and it means that academic staff are satisfied (Amaraesena et al., 2015, p. 547). Another study (Khalid, 2012, p. 130131) obtained at universities in Pakistan (both state universities and private ones) indicated differences in compensation between state and private universities. Teachers as employees in the private sector are satisfied with their payment and promotion, while employees at state universities are satisfied with the nature of work and job security. One more study, conducted by authors Machado et al. (2011) indicated that general job satisfaction is higher at private universities than at state universities. Among the analyzed partial indicators, satisfaction with the nature of job is the highest and satisfaction with compensation is the least. The results of this study indicate that teachers are more satisfied than assistants. The level of general job satisfaction measured on a 10-point Likert's scale is 6.7 (Machado et al, 2011, p. 1720).

The results of job satisfaction research conducted at the Faculty of Agriculture in Belgrade (Serbia) indicated that employees are satisfied with flexible working hours, but dissatisfied with payment, which is highly important since it has been found that pay satisfaction is related positively to commitment (Adeoye, 2019). The level of general job satisfaction measured by a 6-point Likert's scale is 3.85 (Popović et al., 2015, p. 38). It is important to highlight that the standard of living in Serbia is lower than in the European Union.

Based on previous research, in the context of research, the authors formulated the present research goals. The first goal is to determine the level of general job satisfaction 
of academic staff at higher educational institution in Serbia. The second goal is to determine the partial job satisfaction of academic staff in Serbia based on partial indicators of job satisfaction: nature of job, co-workers, pay, promotion, contingent rewards, flexible benefits, communication, supervision and job procedures (Spector, 1997, p. 4).

\section{Methodology}

To determine the level of job satisfaction of academic staff, the authors performed a pilot research and used Spector Job Satisfaction Survey (JSS) (Spector, 1997) officially translated into Serbian language (Branko Mladenović, 2013), using a 6-point Likert's scale. The first part of the questionnaire contains 36 questions. The second part of the questionnaire contains 19 questions on demographic and organization data. For data process and data analysis IBM SPSS version 23 was used.

The value of general job satisfaction on the sample of 58 employees is determined by a JSS questionnaire (Spector, 1985; Spector 1997), items 1-36. The questionnaire implements Likert's 6-point scale, where 1 refers to 'I highly disagree' and 6 refers to 'I highly agree'. The results can range from 36-216, so the results from 36 to 108 represent dissatisfaction with the job, the results between 108-144 represent ambivalence, while results ranging from 144 to 216 represent satisfaction with the job.

The JSS questionnaire measures partial job satisfaction, too: satisfaction with the nature of the job (items 8,17,27,35), coworkers (items 7,16,25,34), pay (items 1,10,19,28), promotion (items 2,11,20,33), contingent rewards (items 5,14,23,32), flexible benefits (items $4,13,22,29$ ), communication (items 9,18,26,36), supervision (items 3,12,21,30) and job procedures (items $6,15,24,31$ ). The sum of the 4 items for each partial indicator may indicate dissatisfaction (if it is less than 4), ambivalence (between 3 and 4) and satisfaction (above 4).

The Cronbach's Alpha coefficient, which measures the internal consistency (reliability) of the scale, was 0.713 for 36 items. This is an acceptable level of internal consistency of the scale (Streiner, 2003).

Table 1 Sample structure according to the type of higher educational institutions

\begin{tabular}{lcc}
\hline Type of institution & Number of respondents & Percent (\%) \\
\hline Faculty & 28 & 48.3 \\
College & 2 & 3.4 \\
College of applied studies & 28 & 48.3 \\
\hline$\sum$ & 58 & 100.0 \\
\hline \multicolumn{2}{c}{ Source: Authors' research }
\end{tabular}

As stated previously, the sample included 58 respondents (Table 1), employed as academic staff at a higher educational institution in the Republic of Serbia (28 employed at faculties, 2 at colleges and 28 at colleges of applied studies).

Analyzing the gender of 58 respondents, 44 (76\%) were women, while 14 (24\%) were men. The observed sample included all working positions at the higher education system in Serbia: at colleges or universities - full professor, associate professor, assistant professor and assistant and employed at college or college of applied studies - professor of applied studies, higher college teacher, college teacher and assistant at college (Table 2). 
Table 2 Sample structure according to the work position of employees at HE institution

\begin{tabular}{lcc}
\hline Work Position at HE institution & Number of respondents & Percent (\%) \\
\hline Full professor & 4 & 6.9 \\
Associate professor & 4 & 6.9 \\
Assistant professor & 11 & 19 \\
Professor of applied studies & 24 & 41.4 \\
Higher college teacher & 1 & 1.7 \\
College teacher & 4 & 6.9 \\
Assistant & 9 & 15.5 \\
College Assistant & 1 & 1.7 \\
\hline$\sum$ & 58 & 100.0 \\
\hline
\end{tabular}

Based on the working position, the sample included 4 full professors (6.9\%), 4 associate professors (6.9\%), 11 assistant professors (19\%), 9 assistants (15.5\%), 24 professors of applied studies $(41.4 \%), 1$ higher college teacher $(1.7 \%), 4$ college teacher $(6.9 \%)$ and 1 assistant at college $(1.7 \%)$. According to the years of work experience, interviewees are grouped as follows: less than 5 years of experience, between 5 and 15 years of experience, between 16 and 20 years of experience, between 21 and 25 years of experience and more than 25 years of experience (Table 3 ).

Table 3 Sample structure according to the years of working experience

\begin{tabular}{lcc}
\hline Years of experience & Number of respondents & Percent $(\%)$ \\
\hline$<5$ & 7 & 12.1 \\
$5-15$ & 25 & 43.1 \\
$16-20$ & 11 & 19 \\
$21-25$ & 7 & 12.1 \\
$>25$ & 8 & 13.8 \\
\hline$\sum$ & 58 & 100.0 \\
\hline \multicolumn{3}{c}{ Source: Authors' research }
\end{tabular}

The sample included 7 employees with less than 5 years of experience (12.1\%), 25 employees with experience between 5-15 years (43.1\%), 11 employees with experience between 16-20 years (19\%), 7 employees with experience between 21-25 years $(12.1 \%)$ and 8 employees with more than 25 years of experience $(13.8 \%)$. According to the age of respondents, they were grouped as follows: aged between 20-29, aged between 30-39, aged between 40-49, aged between 50-59 and more than 60 years old (Table 4).

Table 4 Sample structure according to the age of respondents

\begin{tabular}{lcc}
\hline Age of employees & Number of respondents & Percent $(\%)$ \\
\hline $20-29$ & 2 & 3.4 \\
$30-39$ & 20 & 34.5 \\
$40-49$ & 13 & 22.4 \\
$50-59$ & 22 & 37.9 \\
$>60$ & 1 & 1.7 \\
\hline$\sum$ & 58 & 100.0 \\
\hline \multicolumn{3}{c}{}
\end{tabular}


The sample included 2 employees aged between 20-29, 20 employees aged between $30-39$ (34.5\%), 13 employees aged between 40-49 (22.4\%), 22 employees aged between $50-59(37.9 \%)$ and 1 employee older than 60.

\section{RESEARCH RESULTS}

The obtained result of 129.86 for general job satisfaction indicates ambivalence. Based on the sample of 58 employees at higher educational institutions in Serbia, the authors found that the employees are neither satisfied with the job, nor are they dissatisfied. Table 5 presents results of general job satisfaction, depending on the type of higher educational institution where employees are employed.

Table 5 General job satisfaction depending on the type of institution

\begin{tabular}{lcc}
\hline Type of institution & Number of respondents & $\begin{array}{c}\text { General job satisfaction - } \\
\text { average }\end{array}$ \\
\hline Faculty & 28 & 132.32 \\
College & 2 & 118.00 \\
College of applied studies & 28 & 128.25 \\
\hline$\sum$ & 58 & 129.86 \\
\hline
\end{tabular}

Source: Authors' research

Employees are most satisfied at faculties (132.32), and least satisfied at colleges (118) and colleges of applied studies (128.25). The average values of general job satisfaction depending on the type of higher educational institution belong to the category of ambivalent general satisfaction.

Table 6 presents the results of general job satisfaction, depending on the work position at the higher educational institution. Assistants (139.22) are the most satisfied ones. The average values of general job satisfaction depending on the work position at higher educational institution belong to category of ambivalent general satisfaction. Based on the obtained values, academic staff is not satisfied, but neither are they dissatisfied with their job.

Table 6 General job satisfaction depending on the work position

\begin{tabular}{lcc}
\hline Work position at HE institution & Number of respondents & $\begin{array}{c}\text { General job satisfaction - } \\
\text { average }\end{array}$ \\
\hline Full professor & 4 & 128.50 \\
Associate professor & 4 & 130.75 \\
Assistant professor & 11 & 126.91 \\
Professor of applied studies & 24 & 127.92 \\
Higher teacher at college & 1 & 114.00 \\
College teacher & 4 & 133.00 \\
Assistant & 9 & 139.22 \\
College Assistant & 1 & 130.00 \\
\hline$\sum$ & 58 & 129.86 \\
\hline
\end{tabular}

Source: Authors' research 
Table 7 presents the results of general job satisfaction, depending on the years of work experience of employees at the higher educational institution. According to the years of experience, the most satisfied ones are employees with less than 5 years of experience (135), while the least satisfied employees are those who have more than 25 years of experience (119.37). The average values of general job satisfaction depending on the years of work experience at a higher educational institution belong to category of ambivalent general satisfaction. Academic staff is neither satisfied, but nor dissatisfied with the job.

Table 7 General job satisfaction depending on the years of work experience

\begin{tabular}{lcc}
\hline $\begin{array}{l}\text { Age of } \\
\text { employees }\end{array}$ & $\begin{array}{c}\text { Number of respondents } \\
\text { <5 }\end{array}$ & $\begin{array}{c}\text { General job satisfaction - } \\
\text { average }\end{array}$ \\
$5-15$ & 7 & 135.00 \\
$16-20$ & 25 & 132.12 \\
$21-25$ & 11 & 129.82 \\
$<25$ & 7 & 128.71 \\
$\sum$ & 8 & 119.37 \\
\hline
\end{tabular}

Source: Authors' research

Table 8 presents results of general job satisfaction depending on the age of employees at a higher educational institution. The most satisfied are employees between 20-29 years of age (155.50) and the least satisfied are employees with more than 60 years (125). According to the measurement system of Spector's JSS questionnaire (Spector 1985, Spector 1997), only one category of respondents (those between 20 and 29 years of age ) is generally satisfied with the job (155.50), since this result falls into the category of job satisfaction (between 144-216). Other employee groups based on their age belong to the ambivalent category.

Table 8 General job satisfaction depending on the age of employees

\begin{tabular}{lcc}
\hline $\begin{array}{l}\text { Age of } \\
\text { employees }\end{array}$ & Number of respondents & $\begin{array}{c}\text { General job satisfaction - } \\
\text { average }\end{array}$ \\
\hline $20-29$ & 2 & 155.50 \\
$30-39$ & 20 & 132.40 \\
$40-49$ & 13 & 123.15 \\
$50-59$ & 22 & 129.41 \\
$>60$ & 1 & 125.00 \\
$\sum$ & 58 & 129.86 \\
\hline \multicolumn{3}{c}{ Source: Authors' research }
\end{tabular}

Table 9 presents the results of partial indicators of job satisfaction at higher educational institutions in Serbia.

Looking at the results of partial job satisfaction calculated with the items entering the individual subscales, the following values have been obtained: satisfaction with the nature of the job (17.34); co-workers (14.81); pay (14.43); promotion (14.16); contingent rewards (13.12); flexible benefits (14.45); communication (13.78); superiors (13.55) and working conditions (14.22). The partial satisfaction scores indicate that teachers in the higher 
education system of Serbia are only satisfied with the nature of the job (grade 17.34 higher than 16), while with other causes of satisfaction, teachers are ambivalent, i.e., neither satisfied nor dissatisfied.

Table 9 Partial job satisfaction at higher educational institutions in Serbia

\begin{tabular}{lrcccc}
\hline & Range & Min & Max & Mean & SD \\
\hline Nature of job & 12.00 & 10.00 & 22.00 & 17.3448 & 3.08677 \\
Co-workers & 9.00 & 10.00 & 19.00 & 14.8103 & 2.06438 \\
Pay & 12.00 & 7.00 & 19.00 & 14.4310 & 3.22334 \\
Promotion & 20.00 & 4.00 & 24.00 & 14.1552 & 4.81154 \\
Contingent rewards & 15.00 & 6.00 & 21.00 & 13.1207 & 2.81024 \\
Flexible benefits & 10.00 & 9.00 & 19.00 & 14.4483 & 1.93012 \\
Communication & 16.00 & 5.00 & 21.00 & 13.7759 & 3.16806 \\
Supervision & 15.00 & 4.00 & 19.00 & 13.5517 & 3.39335 \\
Job procedures & 12.00 & 9.00 & 21.00 & 14.2241 & 2.54119 \\
\hline \multicolumn{5}{c}{ Source: Authors' research }
\end{tabular}

\section{DISCUSSION AND PRACTICAL IMPLICATIONS}

Based on the results of the survey conducted on a sample of 58 respondents employed in higher educational institutions in Serbia, on the level of general and partial job satisfaction it can be concluded that the employees are not satisfied with their work, but they are not dissatisfied, either, therefore there is an ambivalent level of general job satisfaction. Analyzing the general job satisfaction of the special subgroups of respondents, it can be stated that employees at faculties are more satisfied than employees in colleges and colleges of applied studies. At faculties, assistants are the most satisfied, while at colleges and colleges of applied studies the most satisfied group are college teachers. Taking into consideration the years of work experience, the most satisfied employees are those who have less than 5 years of service, while based on age, the most satisfied employees are those between 20 and 29 years of age.

Similar research conducted by authors Nandan \& Krishna (2013) indicated that the more satisfied employees tend to be the younger population at junior positions, because they have a motive to prove themselves in research work, while their older colleagues spend more time with family (Slavić \& Avakumović, 2018, p. 1219).

Analyzing indicators of partial job satisfaction (nature of job, co-workers, pay, promotion, fringe benefits, contingent rewards, communication, supervision and working conditions), the authors conclude that employees are most satisfied with nature of job, and least satisfied with supervision, communication and pay. Similar results can be found in the research of Popović et al. (2015) and Saiti \& Papadopoulos (2014) which indicated that academic staff is most satisfied with nature of job, and least satisfied with compensation (pay, fringe benefits and contingent rewards) (Slavić \& Avakumović, 2018, p. 1218-1219).

During the analysis of the research results on job satisfaction it is important to factor in the country's situation where the research is conducted, because there are significant differences between national income in different socio-economic systems. Sometimes in lessdeveloped countries it is not possible to increase the salary and give rewards, and because of that it is impossible to react to indicators of partial satisfaction with compensation (Popović et al., 2015, p. 38). 
In this paper two research goals were formulated. The results of the general job satisfaction indicate that teachers are generally ambivalently satisfied with their job, they are not satisfied, but neither are they dissatisfied. The research results on partial job satisfaction confirmed that respondents are satisfied with the nature of job. Among the analyzed nine indicators of partial job satisfaction, satisfaction with the nature of job ranks highest.

\section{CONCLUSIONS}

Job satisfaction is an important factor in the field of human resource management, based on employee`s perception. The factors influencing job satisfaction can be classified as factors associated with the job (working environment, the nature of the task, relations with other people at the workplace) and individual factors (personality and prior experiences). The adequate measurement of job satisfaction is of key importance, because results may indicate significant differences between employees' expectations of the job and what the job truly offers.

Job satisfaction of staff employed at higher educational institutions refers to the effective relation of teachers to their role as lecturers and function of observed relation between what employees expect from teaching and what the educational institution really offers. Satisfaction of academic staff brings benefits to teachers, students, as well as to the educational institutions themselves.

The aim of this paper was to determine the level of general and partial satisfaction of teaching staff at the institutions of higher education in the Republic of Serbia.

The results of the general job satisfaction indicated that teachers are generally ambivalently satisfied with their job, they are not satisfied, but neither dissatisfied, except for the respondents between 20 and 29 years of age.

The limitation of this research is the small and non-representative sample. Present authors plan to conduct the same research on a larger sample, which will represent the type and ownership of higher education system of Serbia, and will include the influence of different HRM activities on job satisfaction.

\section{REFERENCES}

Adeoye, A.O. (2019). Compensation Management and Employees' Motivation in the Insurance Sector: Evidence from Nigeria. Facta Universitatis, Series: Economics and Organization, 16 (1), 31-47. https://doi.org/10.22190/ FUEO1901031A

Ali P. (2009). Job satisfaction characteristics of higher education faculty by race. Educational Research and Review, 4(5), 289-300.

Almutowa, Z., Muenjohn, N. \& Zhang, J. (2015). Unlocking the black box of the conceptual relationship between system and organizational performance. Proceedings of the Australasian Conference on Business and Social Sciences. Sydney (in partnership with The Journal of Developing Areas).

Al-Rubaish, R. \& Wosornu, A. (2011). Academic job satisfaction questionnaire: Construction and validation in Saudi Arabia. Journal of Family and Community Medicine, 18 (1), 1-7. https://doi.org/10.4103/1319-1683.78630

Amarasen, T.S.M., Ajward, A.R. \& Ahasanul Hoque, A.K.M. (2015). Does Social Recognition Impact Job satisfaction of Academic Faculty Members of State Universities in Sri Lanka. International Journal of Recent Advances in Organizational Behaviour and Decision Sciences (IJRAOB) An Online International Research Journal, 1 (4), 540-553. 
Andreassi J., K., Lawter, L., Brockerhoff, M. \& Rutigliano, P. (2014). Cultural impact of human resource practices on job satisfaction: A global study across 48 countries. Cross Cultural Management, 21 (1), 5577. https://doi.org/10.1108/CCM-05-2012-0044

Azumah A.A., Mohammed S. \& Tetteh R., (2017) An empirical study of Job satisfaction of university staff, Sunyani Technical University, May 20th, 1-13.

Bodla, A., Hussain, M. \& Chen, C. (2014). Determinants of Job Satisfaction in Academic Professionals of Pakistan. Journal of Management and Business, 1, 20-39. DOI: https://doi.org/10.30537/sijmb.v1i1.75

Bogićević Milikić B. (2019). Promoting gender-responsive talent management in police organizations through strategic HRM measuring. Strategic Managament, 24(1), 19-29. https://doi.org/10.5937/StraMan1901019B

De Lourdes Machado, M., Soares, V.M., Brites, R., Ferreira, J.B. \& Govueia, O.M.R. (2011). A look to academics job satisfaction and motivation in Portuguese higher educational institution. Procedia - Social and Behavioral Sciences, 29, 1715 - 1724. https://doi.org/10.1080/03075079.2014.942265

Đorđević, B., Petković, M. \& Đukić, S. (2018). Organizaciona pravda: sredstvo za upravljanje preostalim zaposlenima u procesu smanjenja preduzeća [Organizational justice - Tool for managing the remaining employees in the process of downsizing]. Teme, 42 (1), 143-165. https://doi.org/10.22190/TEME1801143D

Đorđević, B., Ivanović-Djukić, M. \& Lepojević, V. (2017). Relationship of ages and gender of the employees in organisations in the Republic of Serbia and their job satisfaction. Economic Themes, 55 (2), 263-280.

Došenović, D. (2018). Job satisfaction articles-comparison upon selected criteria. Facta Universitatis, Series: Economics and Organization, 15 (4), 363-378. https://doi.org/10.22190/FUEO1804363D

Gius, M. (2013). The effects of merit pay on teacher job satisfaction. Applied Economics, 45 (31), 4443-4451. https://doi.org/10.1080/00036846.2013.788783

Hadžić, O. \& Nedeljković, M. (2010). Motivacija za rad i zadovoljstvo poslom u organizaciji [Motivation for work and job satisfaction in the organization]. Novi Sad, Srbija: Tehnički fakultet Univerziteta Novi Sad.

Hebib, E. \& Spasenović, V. (2011). Školski sistem Srbije - stanje i pravci razvoja [Serbian school system - state and directions of development]. Pedagogija, 3 (11), 373-383.

Houston, D., Meyer, L.H. \& Paerwai, S. (2006). Academic Staff Workloads and Job Satisfaction: Expectations and values in Academe. Journal of Higher Education Policy and Management, 28 (1), 17-30. https://doi.org/10.1080/ 13600800500283734

Ivanović-Đukić, M., Đorđević, B. \& Lepojević, V. (2018). Mediating effects of educational level on job related characteristics: Job satisfaction relationship. Strategic Management, 23 (2), 13-21. https://doi.org/10.5937/ StraMan1802013I

Jednak, S., Kragulj, D. \& Parežanin, M. (2018). Knowledge and industry clusters as drivers of economic development and competitiveness. Anali Ekonomskog fakulteta u Subotici, (39), 3-17. https://doi.org/10.5937/ AnEkSub1839003J

Jošanov-Vrgović, I. (2012). Zadovoljstvo poslom i organizaciona privrženost zaposlenih u obrazovnim institucijama [Job satisfaction and organizational commitment of employees in educational institutions]. Doktorska disertacija, Univerzitet Novi Sad, Republika Srbija.

Jovanović, M. (2018). Innovation of Serbia in relation to neighboring countries as a determinant of competitiveness. Ekonomika, 64 (1), 65-78. https://doi.org/10.5937/ekonomika1801065J

Jovanović-Kranjec, M. \& Despotović, D. (2018). Importance of cooperation between Universities and industry as a factor of economic and social development of the Republic of Serbia. Ekonomika, 64 (1), 123-133. https://doi.org/10.5937/ekonomika1801123J

Khalid, S., Irshad, M.Z. \& Mahmood, B. (2012). Job Satisfaction among Academic Staff: A Comparative Analysis between Public and Private Sector Universities of Punjab, Pakistan. International Journal of Business and Management, 7 (1), 126-136. http://doi.org/10.5539/ijbm.v7n1p126

Khan, F., Yusoff, R. \& Khan, A. (2014). Effect of Human Resource Practices on Job satisfaction in Pakistan. Sains Humanika, 1 (1), 53-57.

Krstić, B., Krstić, M. \& Đekić, I. (2018). Sustainability of development and growth crisis, distribution of income and inequality. Economics of Sustainable Development, 2 (1), 1-12.

Locke, E.A. (1976). The nature and causes of job satisfaction. In M. D. Dunnette (Ed.), Handbook of Industrial and Organizational Psychology (pp. 1297-1349). Chicago: Rand McNally College Publishing Company.

Mudor, H. \& Tooksoon, P. (2011). Conceptual framework on the relationship between human resource management practices, job satisfaction, and turnover. Journal of Economics and Behavioral Studies, 2 (2), 41-49. https://doi.org/10.22610/jebs.v2i2.220

Munir, S. \& Khatoon, T. (2015). Job Satisfaction Scale. International Journal of Multidisciplinary Research and Development, 2 (8), 454-457. 
Nandan, D.R. \& Krishna, S.R. (2013). Determinants of Job Satisfaction of Faculty in Higher Education. The Indian Journal of Industrial Relations, 49 (1), 132-147.

Newstrom, J.W. (2007). Organizational Behavior. New York, USA: McGraw Hill.

Nigama K., Selvabaskar S., Surulivel S.T, Alamelu R. \& Uthaya Joice D. (2018). Job satisfaction among school teachers. International Journal of Pure and Applied Mathematics, 119 (7), 2645-2655.

Pham-Thai, N.T., McMurray, A.J., Muenjohn, N. \& Muchiri, M. (2018). Job engagement in higher education. Personnel Review, 47 (4), 951-967. https://doi.org/10.1108/PR-07-2017-0221

Popović B., Maletić R. \&Paunović T. (2015). Employee satisfaction survey in function of business improvement. Management: Journal for Theory and Practice Management, 20 (76), 31-40. http://doi.org/10.7595/management. fon. 2015.0021

Qazi, S. \& Jeet V. (2017). Impact of Prevailing HRM Practices on Job Satisfaction: A Comparative Study of Public and Private Higher Educational Institutions in India. International Journal of Business and Management, 12 (1), 178-187. https://doi.org/10.5539/ijbm.v12n1p178

Runhaar, P. \& Sanders, K. (2016). Promoting teachers' knowledge sharing. The fostering roles of occupational self-efficacy and Human Resources Management. Educational Management Administration \& Leadership, 44 (5), 794-813. https://doi.org/10.1177/1741143214564773

Runhaar, P. (2017). How can schools and teachers benefit from human resources management? Conceptualising HRM from content and process perspectives. Educational Management Administration \& Leadership, 45 (4), 639-656. https://doi.org/10.1177/1741143215623786

Saitti, A. \& Papadopoulos, Y. (2015). School teachers' job satisfaction and personal characteristics: A quantitative research study in Greece. International Journal of Educational Management, 29 (1), 73-97. https://doi.org/10.1108/IJEM-05-2013-0081

Shamina, H. (2014).Impact of job satisfaction on professional commitment in higher education. Galaxy International Interdisciplinary Research Journal, 2 (2), 1-11.

Slavić, A. \& Avakumović, J. (2018). Job satisfaction of employees in the higher education. 2nd International scientific conference on IT, Tourism, Economics, Management and Agriculture - ITEMA 2018 (pp. 12141222), Graz, Austria: Association of Economics and Managers of the Balkans, Belgrade, Serbia.

Spector, P.E. (1997). Job Satisfaction. London, New Delhi: Sage Publications.

Stankovska, G., Angeloska, S., Osmani, F. \& Grncarovska, S. (2017). Job Motivation and Job Satisfaction among Academic Staff in Higher Education. Current Business and Economics Driven Discourse and Education: Perspectives from Around the World. BCES Conference Books. Sofia: Bulgarian Comparative Education Society, 15, 159-166.

Statistical Pocketbook of Serbia, (2018). Statistical Office of the Republic of Serbia, Belgrade

Strategy on Scientific and Technological development of the Republic of Serbia for the period 2016-2020, (2016). Ministry of Education Science and Technological development of the Republic of Serbia.

Streiner, D.L. (2003). Starting at the beginning: an introduction to coefficient alpha and internal consistency. Journal of Personality Assessment, 80 (1), 99-103. https://doi.org/10.1207/S15327752JPA8001_18

Sukirno. (2017). Modeling Academic Professional Performance in Higher Education. International Journal of Environmental \& Science Education, 12 (8), 1689-1708.

Szabó Sz., Slavić A., Berber N. (2019). Coaching and its effects on individual and organizational performances in Central and Eastern Europe. Anali Ekonomskog fakulteta u Subotici, 55 (41), 67-80. https://doi.org/10.5937/ AnEkSub1941067S

The Law on Higher Education of the Republic of Serbia. (2005). Official Gazette of the Republic of Serbia, 76.

The Law on Higher Education of the Republic of Serbia. (2017). Official Gazette of the Republic of Serbia, 88.

Toker, B. (2011). Job satisfaction of academic staff: an empirical study on Turkey. Quality Assurance in Education, 19 (2), 156-169. https://doi.org/10.1108/09684881111125050

Trivellas, P. \& Santouridis, I. (2016). Job satisfaction as a mediator of the relationship between service quality and organizational commitment in higher education. An empirical study of faculty and administration staff. Total Quality Management, 27 (2), 169-183. https://doi.org/10.1080/14783363.2014.969595 


\title{
ZADOVOLJSTVO POSLOM NASTAVNOG KADRA U VISOKOM OBRAZOVANJU SRBIJE: PILOT ISTRAŽIVANJE
}

\begin{abstract}
U današnjem turbulentnom poslovnom okruženju konkurentnost organizacija prevashodno je bazirana na nematerijalnim resursima. Kako je konkurencija sve snažnija, stalna aktualizacija kompetencija zaposlenih nameće se kao imperativ dugoročnog opstanka organizacije. Posebnu odgovornost u tom procesu zauzima visokoškolsko obrazovanje, koje obezbeđuje nadogradnju i pruža dalji razvoj prethodno stečenih kompetencija budućih zaposlenih. Visoko obrazovanje je sistem u kojem se stvaraju i prenose znanja kroz proces istraživanja i odvijanja nastave. (Houston et al, 2006, 17) Predavači imaju ključnu ulogu u razvoju kompetencija polaznika. Sadržaj i metode obuke određuju rezultate procesa obuke, odnosno novostečeno znanje, sposobnosti i osećanja polaznika. Kvalitet nastave u velikoj meri zavisi i od zadovoljstva nastavnog kadra. (Runhaar, 2017, 646-647) Cilj rada je utvrditi nivo opšteg $i$ parcijalnog zadovoljstva nastavnog kadra u visokoškolskim ustanovama $u$ Republici Srbiji. Kao metod utvrđivanja nivoa zadovoljstva korišćen je Spektorov Job Satisfaction Survey upitnik (Spector, 1985), koji je postavljen kao on-line upitnik. Istraživanje je sprovedeno tokom decembra 2018-te i januara 2019-te godine. Uzorak predstavlja 58 ispitanika, zaposlenih u nastavi na visokoškolskim ustanovama u Republici Srbiji. Rezultati opšteg nivoa zadovoljstva ukazuju na ambivalentnost zadovoljstva poslom nastavnog osoblja. Posmatrajući parcijalne nivoe zadovoljstva, nastavno osoblje je najzadovoljnije prirodom posla.
\end{abstract}

Ključne reči: visoko obrazovanje, zadovoljstvo poslom, zadovoljstvo nastavnog kadra, opšte zadovoljstvo poslom, parcijalni pokazatelji zadovoljstva 